\title{
A student's perspective: are medical students adequately trained in BLS?
}

This article was published in the following Dove Press journal:

Advances in Medical Education and Practice

25 November 2016

Number of times this article has been viewed

\author{
Tobi Oyewole' \\ Folashade Oyewole ${ }^{2}$ \\ 'University of Liverpool - The School \\ of Medicine, Liverpool, ${ }^{2}$ Imperial \\ College London, London, UK
}

\section{Dear editor}

We read with great interest the article by Lami et al regarding improving basic life support (BLS) training for medical students. ${ }^{1}$ We agree that BLS skills are vital for junior doctors. The days of trial by fire have long gone away, and junior doctors and medical students need to feel that they are adequately trained to handle emergency situations they may face in hospital.

As fifth year medical students we are usually encouraged to emulate our junior doctor colleagues, learning to take histories, and do examination or do minor procedures on the wards. However, dealing with a real life emergency seems to be the last hurdle where more encouragement may be required. University of Liverpool has recently started to emphasize the importance of BLS competence, which is something I only hope will prepare my peers and to feel confident in using these BLS skills on the wards.

The author is right that both regular reinforcement and test are vital to improve retention of already learnt BLS skill. For example, we believe this can easily be done by including BLS in medical student's final examination as one of their core competences, and this would motivate students to regularly update and practice their BLS skill instead of requiring full retraining.

Furthermore, we believe that more effort is needed to promote interprofessional training of dealing with emergency situation, which would give medical students a more enriched and valuable experience of what it is really like on the wards. Currently most students are given BLS training apart from their future peers and colleagues; training together would give students the chance to understand the strengths of other members of the healthcare team and give them firsthand experience of working in a multidisciplinary team.

In conclusion, we agree that "early training of BLS with regular reinforcement" is the way forward. The next question to answer is how early to start with BLS training and whether national examinations for final year medical students would improve junior doctors' skills from the onset and compel universities to provide an adequate training.

\section{Disclosure}

The authors report no conflicts of interest in this communication.

\section{Reference}

1. Lami M, Nair P, Gadhvi K. Improving basic life support training for medical students. Adv Med Educ Pract. 2016;7:241-242.

- The School of Medicine, Liverpool, UK

Email tobioyewole@aol.com 
Dove Medical Press encourages responsible, free and frank academic debate. The content of the Advances in Medical Education and Practice 'letters to the editor' section does not necessarily represent the views of Dove Medical Press, its officers, agents, employees, related entities or the Advances in Medical Education and Practice editors. While all reasonable steps have been taken to confirm the content of each letter, Dove Medical Press accepts no liability in respect of the content of any letter, nor is it responsible for the content and accuracy of any letter to the editor.

Advances in Medical Education and Practice

Dovepress

\section{Publish your work in this journal}

Advances in Medical Education and Practice is an international, peerreviewed, open access journal that aims to present and publish research on Medical Education covering medical, dental, nursing and allied health care professional education. The journal covers undergraduate education, postgraduate training and continuing medical education including emerging trends and innovative models linking education, research, and health care services. The manuscript management system is completely online and includes a very quick and fair peer-review system. Visit http://www.dovepress.com/testimonials.php to read real quotes from published authors.

Submit your manuscript here: http://www.dovepress.com/advances-in-medical-education-and-practice-journal 